\title{
解説
}

\section{再生可能エネルギー固定化を目指した有機ハイドライド 電解合成に関する研究}

\section{松岡 孝司，三好 康太，佐藤 康司（技術賞・棚橋賞）}

近年, 太陽光発電, 風力発電などの再生可能エネルギーの 発電コスト低下に伴い，これらを水素や水素キャリアに変換， 固定化し，貯蔵・輸送する取り組みが進んでいる1.

我々は，有機ハイドライドの1つであるメチルシクロへキ サン $(\mathrm{MCH})$ に注目し, 研究開発を進めている. MCH は, 水 素エネルギー密度が高いだけでなく, 常温・常圧で安定な液 体である。したがって, 既存の石油インフラを活用し, 大量 の水素エネルギーを輸送, 貯蔵することが可能であり, エネ ルギーセキュリティの観点でも優れた水素キャリアと言える.

一方で, 海外の安価な再生可能エネルギーを $\mathrm{MCH}$ に変換 して運搬する際の課題点として, 製造時の発熱口スが大きい ことや設備コストが高いことが挙げられる。この問題を解決 するため, トルエンを再生可能エネルギー由来の電力から直 接合成する Direct $\mathrm{MCH}^{\mathrm{TM}}$ プロセスを考案した ${ }^{2-5}$. Figure 1 に, 水電解と Direct $\mathrm{MCH}^{\mathrm{TM}}$ プロセスの比較を示す. Direct $\mathrm{MCH}^{\mathrm{TM}}$ では, 電気化学的にトルエンを還元することで水素ガスを介 さずに $\mathrm{MCH}$ を製造することができる，従来プロセスでは， 水電解装置の他に, 水素タンク, 化学水素化プラントなどの 設備が必要であったが，Direct MCH ${ }^{\mathrm{TM}}$ プロセスでは必要な設 備が電解装置のみになり, CAPEX（設備費などの資本支出） を大幅に低減することができる，さらに，発熱反応である $\mathrm{MCH}$ 合成反応の発熱口スも削減することができるため, OPEX（電気代等の運営費）の観点でのコスト削減も期待で きる。

開発当初, Direct $\mathrm{MCH}^{\mathrm{TM}}$ プロセスの課題は，工業的な電流 密度や高い $\mathrm{MCH}$ 生成のファラデー効率が得られる電解槽の 開発を行うことであった。この開発では, 自社で保有する固 体高分子形燃料電池の触媒や触媒層形成技術, 石油化学プロ セスで培ったシミュレーション技術等を活用し，さらには電 解槽, 電極メーカー, 大学等からも技術協力を得ることで, 2018 年度までに商用アルカリ水電解と同等の電流密度 $\left(>0.4 \mathrm{~A} \mathrm{~cm}^{-2}\right)$ とファラデー効率 (>95\%) を両立する Direct $\mathrm{MCH}^{\mathrm{TM}}$ の小型電解槽（電極面積 $: 100 \mathrm{~cm}^{2}$ ) の開発に成功し た。また，2019年度には，これらの電解槽と豪州クイーンズ ランド州の太陽光発電を用いて, MCH の電解合成を行い,

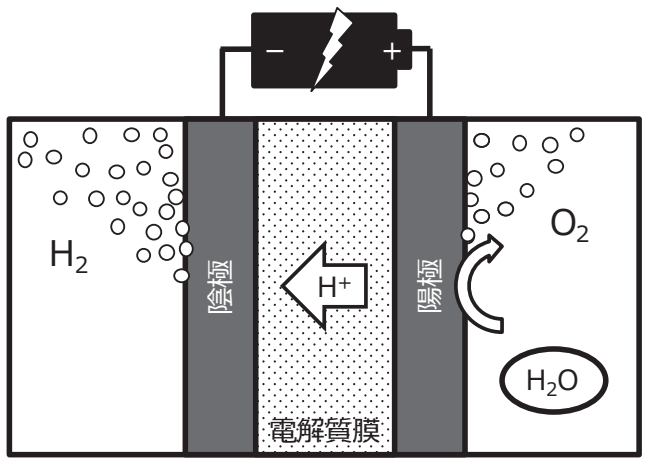

陰極: $2 \mathrm{H}^{+}+2 \mathrm{e}^{-} \rightarrow \mathrm{H}_{2}$

陽極: $\mathrm{H}_{2} \mathrm{O} \rightarrow 1 / 2 \mathrm{O}_{2}+2 \mathrm{H}^{+}+2 \mathrm{e}^{-}$

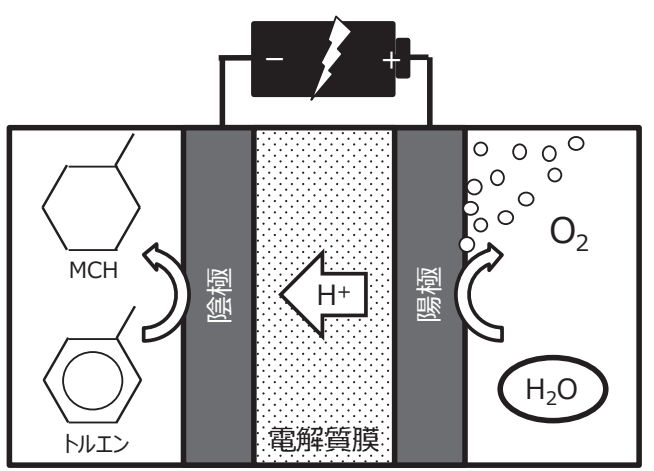

陰極: $\mathrm{C}_{7} \mathrm{H}_{8}$ (トルエン) $+6 \mathrm{H}^{+}+6 \mathrm{e}^{-} \rightarrow \mathrm{C}_{7} \mathrm{H}_{14}(\mathrm{MCH})$ 陽極: $3 \mathrm{H}_{2} \mathrm{O} \rightarrow 3 / 2 \mathrm{O}_{2}+6 \mathrm{H}^{+}+6 \mathrm{e}^{-}$

Figure 1. 水電解と Direct $\mathrm{MCH}^{\mathrm{TM}}$ の模式図.

日本に輸送, 脱水素して水素を取り出すという一連の技術検 証を行っている. 本検証では, 燃料電池自動車で約 $30 \mathrm{~km} の$ 航続距離に相当する約 $2200 \mathrm{~L}$ （常温常圧）を日本で取り出す ことに成功した ${ }^{6}$.

Figure 2 に当社の Direct $\mathrm{MCH}^{\mathrm{TM}}$ 電解槽のスケールアップの 計画を示す. 電解槽の面積拡大は, ステップを踏んで行って いく必要があり, 現在は, 小型電解槽を高さ方向に拡大した 電解槽の開発を進めている. 2022 年には大型電解槽のベース となる電極面積 $3 \mathrm{~m}^{2}$ 級中型電解槽を完成・実証試験を行い, 2025 年には大型電解槽完成を目指して開発を進めている. 


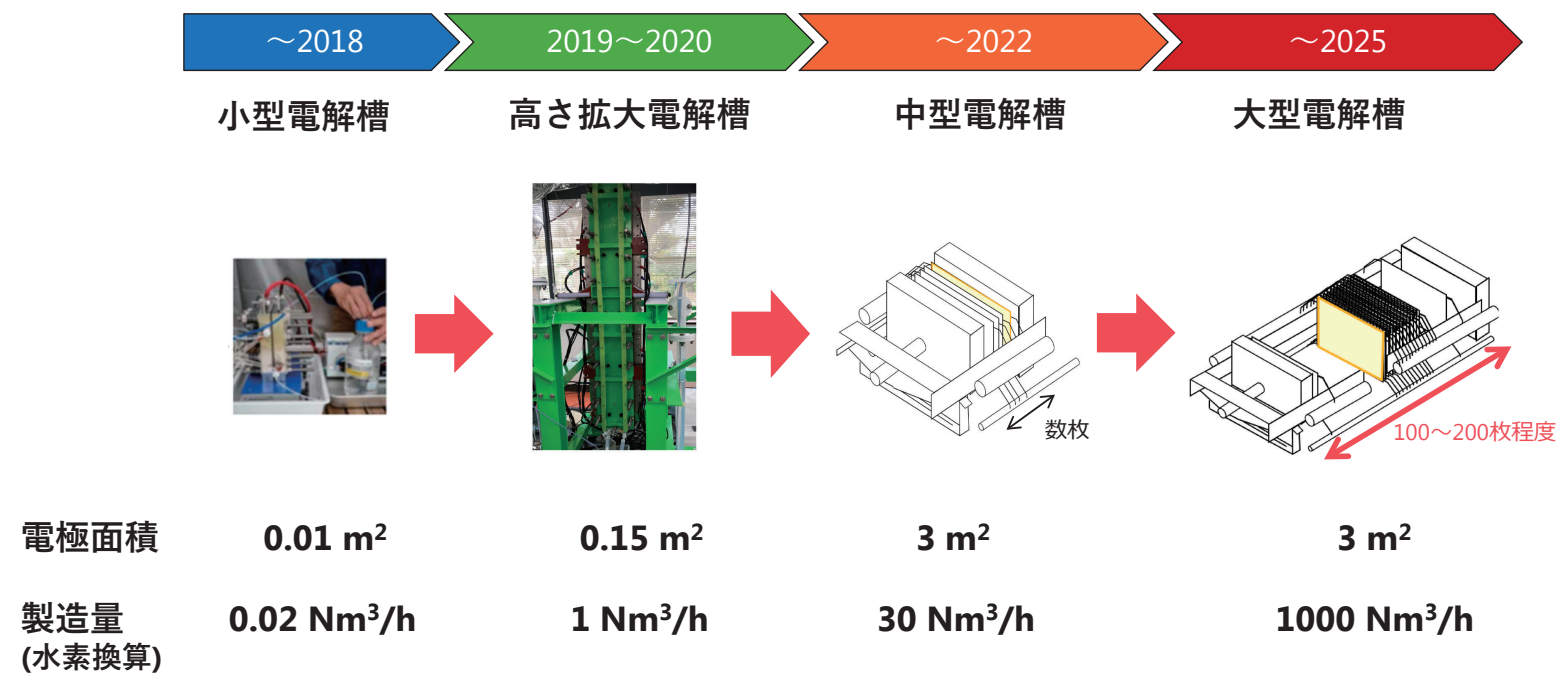

Figure 2. 当社の Direct $\mathrm{MCH}^{\mathrm{TM}}$ 電解槽スケールアップの計画.

\section{文 献}

1. 2019 Annual Merit Review and Peer Evaluation Report, DOE, USA.

2. K. Miyoshi, et al., $224^{\text {th }}$ ECS Meeting, Abstract \#759 (2013).

3. K. Matsuoka et al., J. Power Sources, 343(1), 156 (2017).

4. 三好康太, JXTG テクニカルレビュー, 61(2), 77 (2018).

5. 松岡孝司, 三好康太, 佐藤康司, 水素エネルギーシステム, 44(4), 256 (2019).

6. JXTG エネルギー株式会社 プレスリリース https://www.noe.jxtg-group.co jp/newsrelease/2018/20190315_01_2011051.html YouTube https://www.youtube. com/watch?v=b-vFzQKdmJA

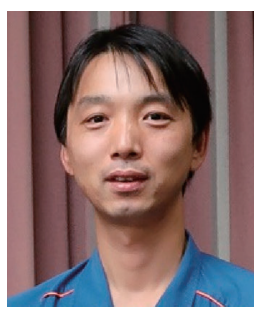

松岡 孝司 (ENEOS 株式会社 中央技術研究所, 担当マネージャー)

1977 年生. 2005 年 3 月京都大学大学院工学研究 科博士後期課程修了，博士（工学）。2005～ 2013 年家庭用燃料電池開発，2013 年〜再工皂 利用に関する研究・開発等に従事。2016年より 現職. 専門分野: 工業物理化学, 電気化学. 趣 味 : 旅行，ゴルフ。

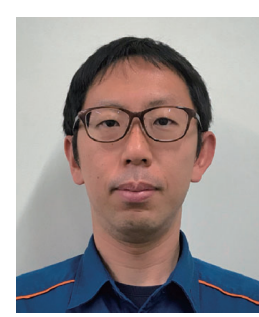

三好 康太（ENEOS 株式会社 中央技術研究所 シニアスタッフ)

1983 年生. 2009 年 3 月横浜国立大学大学大学院 工学研究科修士課程修了。2009 年 4 月に新日本 石油株式会社（現 ENEOS 株式会社）に入社し, 燃料電池システム, 電解技術等の開発等に従事. 専門分野：応用電気化学. 趣味：野球，テニス。

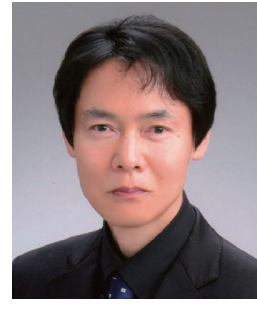

佐藤 康司 (ENEOS 株式会社 中央技術研究所 先進技術研究所長)

1968 年生. 1994 年 3 月東京大学大学院工学系研 究科修士課程修了, 博士 (工学)。2001-13 年家 庭用燃料電池開発等に従事. 2014 年より再エネ 利用研究グループマネージャーを経て，2020年 4 月より現職。専門分野: 有機合成, 触媒化学. 趣味 : 真空管オーディオ. 